\section{ANGLO-SOVIET SCIENCE} \section{Hope for the Future?}

A CEMENTING of relations between Britain and the Soviet Union in the applied scientific, technological, trade and economic fields took place in Moscow last week.

This was at the second meeting of the permanent United Kingdom/USSR inter-governmental commission (Joint Commission) for cooperation in these fields, the first of which was held in January 1971. After that meeting, enthusiasm for the aims of the Joint Commission waned, but last October a ten day visit to Britain by a delegation from the Soviet State Committee for Science and Technology put much needed life into Soviet-British relations in science and technology.

The British delegation to Moscow was led by Mr Peter Walker, Secretary of State for Trade and Industry, while the Soviet group at the meeting was led by Academician V. A. Kirillin.

The Joint British/Soviet Commission called for a greater cooperation between scientific research organizations and companies in the two nations.

But the communiqué released from Moscow after the meetings last week is more a statement of intent than a plan for action. It is clear that both sides expressed willingness to cooperate and exchange ideas, but the driving force to get cooperative ventures off the ground must come from the scientists and from industry. The communiqué makes special mention of collaboration that already exists-for example, in plasma physics, where scientists from the Culham Laboratory of the United Kingdom Atomic Energy Authority are collaborating with their Soviet counterparts and also in radio astronomy.

The new lease of life given to the Joint Commission by last week's meeting means that both Britain and the United States now have an effective machinery for cooperation with the Soviet Union. An agreement was signed between the United States and the Soviet Union in May 1972 effectively setting up a committee very similar to the one that met last week (see Nature, 237, 247 ; 1972).

But how does cooperation work from the British side? Before the Joint Commission was set up in January 1971 there were in existence several working groups on specific technological and scientific problems which were set up in 1967-68 under the auspices of the Confederation of British Industry and the Soviet State Committee. One of the articles of the agreement which set up these committees stated that there should be exchange visits between applied scientists and technologists in
Britain and the Soviet Union. This was designed to complement the already existing, and active, exchange programme between the Royal Society and the Soviet Academy, which chiefly caters for pure scientists. But from the British point of view the exchanges under the 1967-68 scheme have not been completely successful. Only a few exchanges have taken place and the British people involved have generally had to pay their own way to Moscow, although during their stay they are sponsored by colleagues in the Soviet Union. The few Soviet scientists to come to Britain have done so on a similar basis.

It is, however, cheerful to note that the next meeting of the Joint Commission has already been set for Londonsometime in 1974.

\section{EDUCATION \\ Sir Brian Defends}

SIR BRIAN FLOWERS, chairman of the Science Research Council, said last week that his council "regarded it as a matter of national importance to further the engineering profession", as little has been done in the training of engineers during the past 20 years. Giving evidence to the Select Committee on Finance in Education and Arts, Sir Brian said that the SRC has attempted to rectify the situation by using "its most powerful weapon-its money".

The universities pay for about half the research studentships in the sciences. The SRC's policy of allocating more grants to applied research was, at first, hindered by the universities allocating more grants to the pure sciences. Now, according to Sir Brian, the situation has changed and considerably more emphasis is being placed on the applied sciences.

This bias towards applied science raised the question as to whether a separate Technical Research Council should be formed-possibly as a branch of the SRC. Sir Brian insisted that "both pure and applied science would suffer" if the SRC was subdivided.

Little information is available about employment of higher degree graduates, but both the select committee and the SRC agreed that better liaison between universities and industry is necessary to ensure that worthwhile research projects are financed.

Sir Brian hotly defended the awarding of fellowship grants, and he spurned the suggestion that these fellowships were just another form of unemployment, saying that they were "a subsidy to real and lasting excellence". $\mathrm{He}$ pointed out that postdoctoral grants are only awarded to a very small proportion of PhDs and their duration is for two years only. Their purpose is to allow a brilliant and original researcher to carry on his project unhindered by any outside pressure.

\section{INDIAN SCIENCE}

\section{Concern over Quality}

from a Correspondent

UNEMPLOYMENT among scientists is as much, if not more, of a problem in India than it is in Britain and North America. There were five times more scientists unemployed in India in 1972 than there were in 1967, whereas unemployed arts and humanities graduates were 3.5 times more numerous in 1972 than they were five years earlier. But twice as many degrees are awarded in the arts than are awarded in the sciences each year.

In 1966-67, 45.5 per cent of the students who enrolled at Indian universities did so to take degrees in scientific and technological subjects. But the percentage has dropped every year since then and in 1970-71 it was as low as 41.4 per cent of the total enrolment.

This is symptomatic of the state of science in India, which has been in the doldrums in recent years in spite of a massive increase in support for scientific research from $\mathrm{R} 1,300$ million in 196768 to $R 2,140$ million in $1971-72$. There is deep concern about this, although ambitious plans are being formulated by scientific groups within India to use science and technology in order to eradicate poverty. At present several Indian scientists hold the rank of secretaries to the government and a phase of evaluation and consolidation in science is taking place.

But there is widespread concern about the quality of the publications of Indian scientists. This concern is not lifted by the results of a survey, carried out by Professor Rais Ahmed of the Indian University Grants Commission on publications of scientists working in India in the fields of spectroscopy, nuclear physics, electronics and solid state physics. The survey shows that in 1969 , for example, 181 Indian scientists were cited in physics abstracts journals as having produced papers in spectroscopy, but in 1971 only 95 were cited. But in the same period the number of names of foreign scientists working in India who had published papers in spectroscopy increased from 100 to 162 . A similar decrease in the numbers of publications by Indian born scientists and increase by foreign scientists was recorded in most of the other fields investigated. The important question, as far as the future of Indian science is concerned, is whether the drop in output is due to an overall decrease in the number of papers published or whether it is due to a widening gap between the standard of science as practised in India and the standard of science elsewhere. 